\title{
Breast Cancer pT1c TNM Finding v6 and v7
}

National Cancer Institute

\section{Source}

National Cancer Institute. Breast Cancer PT 1C TNM Finding v6 and v7. NCI Thesaurus.

Code C48982.

Breast cancer with tumor size more than $1.0 \mathrm{~cm}$, but not more than $2.0 \mathrm{~cm}$ in greatest dimension. (from AJCC 6th and 7th Eds.) 